\title{
Child-headed households because of the trauma surrounding HIV/AIDS
}

\author{
Zamani Maqoko \& Yolanda Dreyer ${ }^{1}$ \\ Department of Practical Theology \\ University of Pretoria
}

\begin{abstract}
By the year 200214 million children had been orphaned globally because of the HIV/AIDS pandemic. A great number of these have become the heads of households, are forced to look after themselves and siblings, drop out of school, are vulnerable to many forms of abuse and have found work to take care of themselves and their siblings. Misinformation, ignorance and prejudice concerning HIV/AIDS limit the willingness of a community to provide for the orphans who have been affected by the disease. This article aims to address the question why this is also the case in South Africa and why the African philosophy of "ubuntu" (humaneness), does not seem to make a difference. This study build upon fieldwork undertaken in the Bophelong area among HIV/AIDS orphans who function as heads of households and children who have been orphaned due to circumstances other than HIV/AIDS. The article concludes that religious communities can fill the gap left by the lack of "ubuntu" and can play a major role in nurturing HIV/AIDS orphans who function as heads of households. Churches can build a supportive environment where HIV/AIDS orphans and other vulnerable children can feel accepted.
\end{abstract}

\section{PROBLEM STATEMENT AND METHODOLOGY}

In 1998 a study by the Department of Health suggested that by 2005 between 197000 and 250000 children would be orphaned in KwaZulu Natal alone. HIV/AIDS has done damage to families and their children (a WCC Study Document 1997:1). According to UNICEF (2003b:9), a joint programme between UNAIDS and the United Nations indicates that in 1996 approximately 20 million people around the world were infected by HIV/AIDS. More than 6 million are already dead (World Bank 1999:13). Statistics (UNAIDS/WHO

\footnotetext{
${ }^{1}$ This article is a reworked version of a section of Zamani Maqoko's MA thesis entitled "HIV/Aids orphans as heads of households: A challenge to pastoral care" (2006), in the Department Practical Theology, Faculty of Theology, University of Pretoria with Prof $\mathrm{Dr}$ Yolanda Dreyer as supervisor.
} 
2003:3) disclose that by 2002 approximately 40 million people worldwide were living with HIV and 2,5 million were children under the age of 15. Globally, by the same year there were 14 million children who were orphaned by the pandemic. A great number of these children have become the heads of households, were forced to look after themselves, dropped out of school, became vulnerable to many forms of abuse and had to look for work in order to care for their siblings.

Child-headed households are not new in the South African society. Although there is not much information regarding child-headed households, the report of Deborah Ewing (in Gow \& Desmond 2002:83) confirms that situations do exists where older siblings often head up households. Other households are headed by children who sometimes have the support of an older person from the neighbourhood. There are also children who care for sick parents and who do not receive any adult support. HIV/AIDS orphans in child-headed households in the South African context are likely to be poorer and less healthy than children who are not orphans. In addition UNICEF (2003b:26) states that AIDS orphans are likely to suffer damage to their cognitive and emotional development, have less access to education and are subjected to the worst forms of child labour. In 2003 there were approximately 43 million orphans in Sub-Saharan Africa (USAID 2004:7). According to SlothNielsen (2004:1), approximately 840000 children in South Africa have lost their mothers, mostly because of HIV/AIDS. By the year 2015 this number is expected to have increased to 3 million.

Research on orphans and other vulnerable youth indicates that official recommendations and programmes have not adequately taken the physical, cognitive, emotional and psychological differences that characterize children and adolescents in different stages of development, into account (UNICEF/UNAIDS/USAID 2004:13). Misinformation, ignorance and prejudice about HIV/AIDS limit the willingness of a community to provide for the orphans who are affected by the disease. UNICEF (2003b:6) formulates it as follows: "[F]rom the beginning the HIV/AIDS epidemic has been accompanied by fear, ignorance and denial leading to silence and inaction by government and to stigma, discrimination and abuse against people with HIV/AIDS and their families."

As the number of people infected with HIV/AIDS increases, access to medical care becomes difficult and expensive for everyone, including those not infected. When parents fall ill, particularly in poor families, children come under duress and the effects of this often continue in different ways for the rest of their childhood. They often take on the heavy burden of nursing their ailing parents because family members and relatives are not willing to help. 
On a psychological level children are traumatized by the illness of their parent(s). This is exacerbated by the stigma and discrimination attached to HIV/AIDS. UNICEF (2003a:2) lists some other experiences these children have:

\section{- Economic hardships}

With parents unable to work and savings spent on health care, children are forced to take on the adult role of supporting the family.

\section{- Having to leave school}

The pressures of having to care for parents and siblings while trying to earn an income, can cause children to drop out of school, even while their parents are still alive. The pressure to abandon schooling intensifies when one or both parents die.

\section{- Malnutrition and illness}

Orphans and other affected children are more likely to be malnourished or to fall ill. They are also less likely to receive the medical attention and healthcare they need. Poverty is the root cause of this vulnerability, but often neglect and discrimination by adults in whose care they have been left, are also contributing factors.

\section{- Loss of inheritance}

When parents die, orphans are often cheated out of property and money that are rightfully theirs.

\section{- Fear and isolation}

Dispossessed orphans are often forced out of their homes to unfamiliar and even hostile places, be they camps for the displaced or the streets.

- Increased abuse and risk of HIV

Impoverished and without parents to educate and protect them, orphans and other affected children face every kind of abuse and risk, including becoming infected with HIV themselves. Many are forced into exploitative and dangerous work, including exchanging sex for money, food, protection or shelter.

This article aims to reflect on these and other conditions experienced by HIV/AIDS orphans. The question which presents itself is why there are so 
many child-headed households? What has happened to "ubuntu" (humaneness), the African philosophy which should help create an environment which is supportive of people in need.

This article builds upon fieldwork consisting of interviews with HIV/AIDS orphans and children who were orphaned due to other circumstances, in the Bophelong area. This region includes new houses made possible by the Reconstruction and Development Programme (RDP) of the government as well as informal settlements ("squatter camps"). The people are mostly from nearby farms and surrounding areas.

The interviews were done with the help of Home and Community Based Care organisations in Bophelong. ${ }^{2}$ The aim of this participatory research was to engage with people in order to gain understanding of their world and experience of their circumstances. In this article they will be referred to as "participants".

Such research presents its own challenges. Neuman (1997:348) is of the opinion that it could disrupt the researcher's personal life, physical security, or mental well-being. In participatory research observation is an ongoing process which should attempt not to upset, disrupt or impose an outside point of view. Frankfort-Nachmias \& Nachmias (1992:273) define such research as "the study of people acting in the natural courses of their daily lives. However the fieldworker is one who ventures into the worlds of others in order to learn firsthand about how they live, how they talk, and behave and what captivates and distresses them." This type of research calls for empathizing with and understanding the existential life stories of people. The HIV/AIDS orphans as heads of the households selected for this study, were engaged with and interviewed at their homes. ${ }^{3}$ The purpose of this was to discover what their and their siblings' real experiences were. The researcher endeavoured to become part of their world as much as possible.

Since the study was conducted with exploratory research in mind, semi-structured interviews were used. Semi-structured interviews are structured in the sense that a list of pertinent issues for investigation is drawn up prior to the interview. Denzin \& Lincoln (2000:649) state that such a list contains some precise questions and their alternatives or sub-questions which depend on the answer to the main question. According to them, semistructured interviews help to clarify concepts and problems. These interviews

\footnotetext{
${ }^{2}$ I had no previous contacts in the area. I found the name and address of Mrs Diphare. She was the coordinator of organisations which deal with orphans and child-headed households in the Gauteng Province. We met and she briefed me on the history of the organisation and the children they were caring for. When she passed away early in 2005 other arrangements had to be made. I was granted permission to conduct the research at Bophelong.

${ }^{3}$ For information about the field research and results of interviewing, see Maqoko (2006).
} 
help to establish a list of possible answers or solutions, which in turn, facilitate the construction of more highly, structured interviews. ${ }^{4}$ This research aimed to ascertain how HIV/AIDS orphans as heads of households adapted, what events meant to them, how they viewed what had happened to them and around them. The main purpose of using interviews in this research was to discover the reality of experiences of HIV/AIDS orphans as heads of households and of their siblings. The researcher wanted to be part of the circumstances they are living in. The study reflects on the complexities in the lives of HIV/AIDS orphans as heads of the households as compared to orphans caused by other circumstances such as accidents and murder. The interviews took the form of an open-ended interview whereby participants were asked the same questions. A list of issues for investigation was drawn up prior to the interview (cf Denzin \& Lincoln 2000:649). The nature of semistructured interviews helps to clarify concepts and problems and allow for the establishment of more highly structured interviews.

Observation was another technique of collecting data for this study. The researcher used the "participant observation" approach because it allowed him to become fully involved in the lives of HIV/AIDS orphans who are heads of households. In this sense the real purpose of the presence of the observer, namely the research project, fades into the background while he becomes a participant in the lives of the interviewees. Becoming an insider or a participant allows for deeper insight into the research problem.

Observing and listening are effective ways of gaining information about the children while they tell their stories and identify troubling issues. By doing this, the observer communicates to the child that he or she is really paying attention, values the information they are giving and respect their view of the world. The researcher took time to observe children in the early phases of childhood who live in child-headed households. Observing a child's behaviour also gives clues as to the underlying emotional states. It is useful to observe whether or not a child's play is age-appropriately creative or stereotypic, repetitive and limited (cf Geldard \& Geldhard 2002:91).

\section{ORPHANS AND CHILD-HEADED HOUSEHOLDS}

An orphan is described as a child who lost one or both parents. UNAIDS (2002) estimate that 660000 children in South Africa have become orphans due to HIV/AIDS. They define an AIDS orphan as a child, aged up to 14 years

\footnotetext{
${ }^{4}$ All interviews were conducted in the vernacular while English words and phrases frequently featured. During the interview a tape recorder was used. Notes were also taken of the responses of the participants during the interview. Translation of the interviews into English was done soon after.
} 
who has lost one or both parents to AIDS. According to Hepburn (2002:88), "orphan" is a socially constructed concept of which the meaning and content vary among cultures and countries. For example, in some cultures it refers to children who have lost one parent, while in other cultures the term is reserved for children who have lost both parents. Lindblade et al (2003) describe an orphan as a child who has lost either or both parents and further refine the categories as maternal, paternal, and double (both parents deceased). Maternal orphans are children whose mother has died but whose father is alive. Similarly paternal orphans are those whose father is dead but the mother is alive.

There are different reasons why children become orphans. SlothNielsen (2004) mentions for instance that children are orphaned or left without adult caregivers on account of fatal car accidents. Parents migrate or otherwise abandon their children. Some parents were snatched and others killed by the apartheid system during the struggle for liberation. Riots during the old apartheid system and black on black violence have also taken their toll. Young children have been left orphaned and vulnerable. Some parents are killed and children left homeless on account of disputes and wars, for example, the disputes in KwaZulu Natal and the civil war between the Qumbu and the Tsolo.

HIV/AIDS has now joined the ranks of these causes for children to become orphaned. The study could not ascertain an exact percentage of orphans who have lost parents due to AIDS, since no statistics which accurately pinpoint the cause of death, are available (see Brookes et al 2004). Yet, it is clear that the increasing effects of the disease jeopardize the rights and well-being of these children. The responsibility of caring for orphans has become a major problem in Africa because poverty and unemployment have made it difficult for families and extended families to cope with the orphans.

In rural areas the most prevalent problems affecting families are education, transport, poverty, unemployment and lately HIV/AIDS. Some AIDS orphans were born before their parents were infected with HIV. Others were not lucky enough to escape it and were also infected because their mothers did not have access to the programme making use of AZT to prevent paediatric transmission. Some children did not contract HIV/AIDS because their parents had undergone this programme. Especially people in rural areas are either not familiar with the AZT preventive programme or otherwise they have difficulty gaining access to it. HIV/AIDS orphans are described by international policy-makers as children aged 15 or younger who have lost either their mother or both parents because of HIV/AIDS. HIV/AIDS orphans are those children who lose their parent(s) through HIV/AIDS related illnesses. 
Manegold et al (2004:8) argue that the impact of poverty and war on children is similar to that of HIV/AIDS. Nearly every child in South Africa will in some way or another experience the impact of HIV/AIDS. This, according to Weinreich \& Benn (2004:46), constitutes a fundamental problem in the fight against HIV/AIDS.

HIV/AIDS orphans are not necessarily also members of a child-headed household. These orphans can be differentiated as double, maternal, or paternal. Double orphans are those whose parents have both died from any cause, not necessarily AIDS. With HIV/AIDS, if one parent is infected, there is a possibility that the other is or will become infected and that both will eventually die. This means that there will be disproportionately large number of orphans as the epidemic advances. Surveys (e.g. UNAIDS 2004:11) show that double orphans are more disadvantaged than single orphans. SubSaharan Africa had almost 7,7 million orphans in 2003 and just over 60 percent of those have lost on their parents due to AIDS. Maternal orphans are those children whose mothers have died and where it is unknown whether the father is still alive. UNAIDS (2004:11) states that AIDS is changing the pattern of orphaning in Sub-Saharan Africa whereby maternal orphans outnumber paternal orphans in five of the most affected countries. The study shows that the rate of women infected by HIV is greater than that of men. Paternal orphans are those children whose fathers have died. These orphans are also called fatherless. It has been discovered that in South Africa one third of paternal orphans do not stay with their mothers. They rather stay with grandparents.

Child-headed households are generally considered to be those where the main caregiver is younger than 18 years of age (Sloth-Nielsen 2004:1). The Constitution of South Africa defines a child as a person younger that 18 , which means that the definition of child-headed households is in line with the Constitution. Sloth-Nielsen (2004) points to the finer distinction made in the relevant literature: "Some authors distinguish between child-headed households and adolescent headed households." An appropriate response to the situation would depend on whether the person heading the household needs more intensive support or less. Sometimes children who still have caregiver, but whose caregivers are terminally ill with HIV/AIDS, though not strictly speaking orphans, would be in the category of child-headed households. When parent(s) become too sick to do what is necessary, these children assume the responsibility of heading the household. As Sloth-Nielsen (2004) puts it: "child-headed households in which there is no effective adult caregiver generally does the same as families: work to support siblings, get food, clothing and shelter, and deal with the emotional well-being of their 
members." Child-headed households, therefore, have a great deal of difficulty trying to provide all of this, especially when there is no income with which to sustain the family.

The available information on child-headed households is limited. As the prevalence of HIV/AIDS increases, the number of orphans who function as heads of households will also increase. Child-headed households are formed when bothers and sisters insist on staying together and refuse to move away from their deceased parent's home. It has been mentioned that the number of infected women is greater than that of men. Hence there is a majority of women willing to take care of orphans. These children will be more vulnerable than children with parental care when these caregivers die. Deborah Ewing (in Gow \& Desmond 2002:83) argues that employed adult siblings of orphans may head households. Other heads of households may be school-going older siblings, children caring for each other with adult support from another household, or children caring for a dying parent with no adult support. In circumstances where children have become caregivers to adults with HIV/AIDS, their childhood is effectively sacrificed. Hence there are community organisations taking the initiative of training and supporting these children who are fulfilling adult roles at the expense of their own security and development.

Children in poor communities who do not have adult caregivers or whose caregivers are dying, are especially vulnerable. This is because there is no adult to give them support and security, or their predicament is due to the fact that the communities in which they live and are growing up, face extreme poverty. As mentioned earlier, child-headed households in which there is no adult caregiver, generally function the same as regular families: they work to support siblings, to obtain food, clothing and shelter, and they concern themselves with the emotional well-being of their members. Orphans in child-headed households face particular challenges and exclusion. These challenges include:

- a serious threat to education because of poverty;

- difficulty in obtaining food and shelter;

- a high risk of being sexually abused by relatives and neighbours;

- the threat of child prostitution and child labour;

- difficulty in getting birth registration done and in procuring healthcare and social security benefits;

- experiencing property grabbing by families and communities.

Some of the experiences of HIV/AIDS orphans as heads of households include the psychological trauma of witnessing a parent's illness, of dealing 
with death, the absence of adult guidance and mentoring, and the unmet need for love and security (Sloth-Nielsen 2004:3). They have difficulty in getting or continuing with schooling and/or obtaining social grants. It is extremely difficult for adolescents who themselves are still in transition to adulthood, to assume the adult role of raising younger siblings after the primary caregiver has died. The greatest challenge faced by these children is finding sufficient food, housing and health care.

Under the Registration Act every citizen in South Africa has to be registered. Such registration as a citizen makes access to the available state resources possible. Sloth-Nielsen (2004:25) states that "receiving social security, placing a child in foster care, and fulfilling many other children's rights depends on registration of birth and gaining an approved identity document." The Children's Bill makes provision for the legal recognition of child-headed households as a type of family unit in our society. This gives the orphans in child-headed household the right to stay together rather than being distributed among families. The problem encountered by the orphans is that they cannot become foster caregivers to their siblings. This is why the Law Commission has introduced a mentor system. These mentors will deal with a number of matters concerning child-headed households. Among others they will administer the day to day functioning of the family unit. As they will undergo training, they can provide emotional and psychological support, assist the children to obtain birth registration documentation, provide advice and counsel, as well as formally receive grants for those who are unable to go and get it themselves.

\section{CHILDREN'S RIGHTS IN THE CONTEXT OF HIV/AIDS}

As a way of alleviating poverty among orphans, child-headed households, and other children who qualify in terms of certain criteria, the government has allocated social assistance in form of money. This money is given to caregivers who look after the children. Social grants have three categories related to children: Child Support Grant (CSG); Foster Grant (FG); and Care Dependency Grant (CDG). All these grants play a vital role in caring for children. Children orphaned by HIV/AIDS may also benefit from these grants, but it depends on the category. Poverty, exacerbated by HIV/AIDS, is causing a growing number of children to be eligible for grants.

Although these grants are meant for vulnerable children there are people who are helping themselves to the money at the expense of the children for whom it was intended. A young girl of 16 who is still at school reports that her aunt does not give her a cent or buy her anything. Instead the aunt pays off her cash loans with the foster grant. A social worker sent to 
investigate has confirmed that the pay card remains with the cash loans people. The aunt picks up the card on payday and then takes it back after she has received the money. Arrangements were made that the community based care coordinator take responsibility for collecting the money and reporting at the end of every month how it was spent on behalf of the child.

The Child Support Grant is paid to the persons responsible for the child's primary care. It is meant for children living in poverty in South Africa. The persons who receive the money may be the parent, a relative or an unrelated member of the community. Presently the child support grant is R180 and is available to children younger than 14 years. Some of the difficulties faced by orphans in child-headed households and other vulnerable children is getting access to the grants since there is no responsible adult to pick up the money (see Sloth-Nielsen 2004:30-31).

The Foster Care Grant is to benefit children who have been formally placed in the care of foster parents by the children's court. In the case of orphans in child-headed households, community based caregivers are granted permission by the court to care for these children, but only if a report from a social worker accompanies the application. The amount payable is R560. This may not cover all their costs, but orphans could at least have a chance to buy food and some clothes. The Foster Care Grant helps somewhat to alleviate poverty among orphans in child-headed households.

The Care Dependency Grant is meant for children up to 18 years old with severe disabilities who require permanent home-based care. It pays R780 per month. This grant is for severe mentally and physically handicapped children (Gow \& Desmond 2002:89; Sloth-Nielsen 2004:29). This grant is means tested, which implies that the combined annual family income must not exceed R48 000 per annum after deductions. Children at terminal stages of AIDS are eligible for this grant, though there is no formal policy to guide practitioners as to whether and when HIV-positive children may be awarded this grant (Gow \& Desmond 2002:89).

It is clear that social grants have played a major role in education since quite a number of orphans who have gained access to grants are able to buy school uniforms, pay their school fees and at least have some money to take to school. According to the World Bank (2002:XVI), "[m]ore that 113 million school-age children are out of school in developing countries, two-thirds of them girls. Of those who enter school, one out of four drops out before attaining literacy." The impact of HIV/AIDS on the entire education system is evidenced primarily in the deterioration of educational services. Teachers stay away (are sick) and die because of HIV/AIDS. 
This adversely affects orphans as it affects all children. Orphans are less likely to be in school and more likely to fall behind or drop out, which of course compromises the development of skills and abilities and future prospects. On numerous occasions HIV/AIDS orphans are scorned by other children, discriminated against and isolated to such an extent that they find it better to stay away from school. Others feel badly when they have no money for a school uniform, to pay their school fees, or pocket money to take to school. The stress of their situation takes its toll on orphaned children's education. For households that have been crippled by HIV/AIDS, it is not easy to cope with the fees of primary education. Hepburn (2002:91) explains some reasons for this as follows:

- the loss income from employment and activities;

- in rural areas, a reduction in farming which decreases income generating potential;

- high costs for health care and medication;

- a growing number of households affected by AIDS are headed by children.

They often become vulnerable to sexual and physical exploitation and HIV infection. To summarize, it has become clear that many of the experiences of HIV/AIDS orphans can be deemed and are experienced as "traumatic". According to Gibson et al (1995:63), "[t]rauma is widespread in society and can have serious effects not only on those exposed to it, but also those who offer help. Even organisations set up to help survivors of trauma can be badly affected unless they building mechanisms to look after themselves."

Since 1994, the South African government has committed itself to protecting children's rights. According to the United Nations Convention on the Rights of the Child, Article 12 (Gow \& Desmond 2002:4), "children have the right to participate in discussions that affect them and due weight should be given to their opinions." On the same note the Minister of Social Development and Welfare, Zola Skweyiya stated that children have fundamental rights that should be protected. In Kenya, the discussion on protecting the rights of children concentrate on unlawful labour activities, sex work and other acts of violence (Ayieko 1997:29). The Committee on the Rights of Children argues that the impact of HIV/AIDS on children's lives is in fact much wider, as it involves a threat to their civil, political, social, cultural and economic rights (Sloth-Nielsen 2004:6). The committee recommends that measures to address HIV/AIDS should be holistic and rights-based. The primary rights of children as mentioned in Section 28 of the Constitution (see Skweyiya 2002; Sloth-Nielsen 2004:7) are the right: 
- to an adequate standard of living;

- to family or parental care, or to appropriate alternative care when removed from the family;

- to basic nutrition, shelter, basic healthcare services and social services;

- to education and leisure;

- to protection from economic and sexual exploitation and child trafficking;

- to be protected from torture or other cruel, inhuman or degrading treatment or punishment.

All these rights are adversely affected by HIV/AIDS. In situations where children live in remote or rural areas, health and other services are less accessible which leave HIV/AIDS orphans in child-headed households very much vulnerable to HIV infection. However, mandatory HIV testing is prohibited and it is regarded as being against the rights of children. The African Charter on the Rights and Welfare of Children states that it will ensure that any child who is parentless or temporarily or permanently deprived of his/her family environment, shall be provided with alternative family care, which includes foster placements or placement in suitable institutions for care of children (Article 25[2]). This will be done only if the children are willing.

The rights of children are applicable to children who grow up in childheaded households. For the purpose of the Constitution, anyone who is younger than 18 is considered to be a child (Section 28[3]). Though presently there are some orphans who have no proper documentation, Section 28(1)(a) states that every child has the right to a name and nationality by birth. Birth registration is important for access to social grants. Sloth-Nielsen (2004:14) points out that also in this regard children infected or affected by HIV/AIDS are often discriminated against. Strict measures prohibiting discrimination of this kind, will benefit infected and affected orphans in child-headed households.

\section{PASTORAL CARE AND COUNSELING}

Religious communities also have a major role to play in the nurturing of HIV/AIDS orphans as heads of households. Gerkin (1997:171) uses the example of Cedric who was supported by church leaders and teachers, which helped him to turn his life into a positive direction. All churches should embark on building a supportive environment where HIV/AIDS orphans and other vulnerable children will feel accepted and supported. Some churches have already taken action against the stigmatisation of HIV/AIDS.

Pastoral care is about pastors functioning as caregivers. Gerkin (1997:11) calls pastoral care the arena within which the pastor is privileged to 
be with people where they live and breathe, succeed and fail, relate intimately and experience alienation. He notes that this work is done in relation to individuals and communities. According to Campbell (1986:23) pastoral care has come to mean "soul care" by wise persons whose spiritual insight and moral rectitude equip them to lead their "flock" to safety. Sharing the same sentiments, Deeks (in Lartey 2003:61) approaches pastoral care from a Christian perspective. He notes that the purpose of pastoral care is "to assist men and women and boys and girls to live as disciples of Jesus". He explores four aims of pastoral care. The first is to encourage people to make their own sense of their experience. The second is to disclose Christian meaning in life. The third is to stimulate men and women to engage in their own conversation with the Christian tradition, and the fourth is to encourage holiness.

The above statements show that the pastoral caregiver has a major role to play especially in preaching, educating, and counselling people. A WCC Study Document (1997:92), however, states that pastoral care is a ministry of presence, which every person, not only pastors, can offer. For most pastoral caregivers pastoral care is intertwined with counselling. That is why we often refer to them together as "pastoral care and counselling". Pastoral counselling is the process of helping people to make healthy choices for their lives.

Pastoral care and counselling are associated with the rural image of a shepherd tending the flock. From this image the word "pastoral" is derived. Campbell (1986:1) points out that some traditional aspects of the pastoral image are not acceptable today, especially those of the priestly function, ministerial authority and helplessness of the Christian "flock". This "pastoral" image emphasizes the caring ministry which is sorely needed when faced by a scourge like HIV/AIDS. Though some people are not infected by HIV/AIDS, nearly all are affected by it directly or indirectly. Therefore, supporting and working with people can make the difference between personal well-being and psychiatric illness. For the church, to leave the buildings and go and suffer with the people where they live, provides the opportunity to reclaim its struggle for human dignity, righteousness and justice. Churches should also protect the human rights of people living with HIV/AIDS nationally and internationally. By witnessing to the gospel of reconciliation churches can help to reconcile families in the context of HIV/AIDS.

It has become clear in this study that HIV/AIDS orphans as heads of households experience psychological trauma and some of them also become victim to physical, emotional and sexual abuse. Churches as faith community are called to be the healing community. Healing in this case could start where humans denounce the stigma associated with HIV/AIDS and provide love, 
care and support. Pastors are needed as mediators and reconcilers between those infected and affected by HIV/AIDS and those not infected or affected. According to Gerkin (1997:82), to be a good pastor is to seek to understand the deepest longings, the secret sins and fears of the people so that this understanding may bring healing and show the afflicted how the God we serve, cares deeply and intimately for them.

The problem addressed in this article is how the devastation of HIV/AIDS causes young, under-aged orphans to have to function as heads of households. The question is whether pastoral care - that of the pastor and that of the entire faith community - has failed, especially in African communities where "ubuntu" added a cultural incentive to care for the needy and destitute. Pastoral questions arising are: where are those uncles, aunts and grandmothers who cared so unconditionally for such children in the past? Why are these orphans not with older caregivers? Is the caring ministry failing today because of HIV/AIDS? To restrict the care of these children to NGO's, FBO's and CBO's is not sufficient. In the present situation of HIV/AIDS orphans functioning as heads of households, home-based care (HBO) should play a major role. The church should provide a caring ministry of comprehensive pastoral care.

\section{Works consulted}

Ayieko, M A 1997. From single parents to child-headed households: The case of children orphaned by AIDS in Kisumu and Siaya districts. New York: University of Illinois.

Brookes, H, Shisana, O \& Richter, L 2004. The National household HIV prevalence and risk survey of South Africa. Cape Town: HSRC.

Campbell, A V 1986. Rediscover pastoral care. $2^{\text {nd }}$ ed. London: Darton, Longmann \& Todd.

Denzin, N K \& Lincoln, Y 2000. Handbook of qualitative research. $2^{\text {ND }}$ ed. Thousand Oaks: Sage.

Geldard, K \& Geldard, D 2002. Counseling children: A practical introduction. $2^{\text {nd }}$ ed. Thousand Oaks: Sage.

Gerkin, C V 1997. An introduction to pastoral care. Nashville, TN: Abingdon.

Gibson, K, Swart, L \& Sandenberg, R 2002. Coping and counseling. Cape Town: Oxford.

Gow, J \& Desmond, C 2002. Impacts and interventions: The HIVIAIDS epidemic and the children of South Africa. Pietermaritzburg: University of Natal.

Lartey, E Y 2003. In living color: An intercultural approach to pastoral care and counseling. $2^{\text {nd }}$ ed. London: Jessica Kingsley.

Lindblade, K A, Odhiambo, F, Rosen, D H \& DeCock, K M 2003. Health and nutritional status of orphans $<6$ years old cared for by relatives in western Kenya. Tropical Medicine and International Health 8(1), 67-72. 
Manegold, J, Richter, L \& Pather, R 2004. Family and community interventionsfor children affected by AIDS. Cape Town: HSRC.

Maqoko, Z 2006. HIV/Aids orphans as heads of households: A challenge to pastoral care. MA thesis, Department of Practical Theology, University of Pretoria.

Neuman, W L 1997. Social research methods: Qualitative and quantitative approaches. $3^{\text {rd }}$ ed. Boston, MA: Allyn \& Bacon.

Skweyiya, Z S T 2002. Child protection week: Conference on children affected by HIV/AIDS. Eskom Conference Centre, Midrand 2 June 2002.

Sloth-Nielsen, J 2004. Realising the rights of children growing up in child-headed households: A guide to laws, policies and social advocacy. Cape Town: Creda Communications.

UNAIDS/UNICEF/USAID 2004. Children on the brink: A joint report of New Orphans estimates and a framework for action. USAID.

UNICEF 2003. Africa's Orphaned Generations. New York: UNICEF.

UNICEF 2003a. Orphans and other children affected by HIV/AIDS. New York: UNICEF.

UNICEF 2003b. Fighting HIV/AIDS: Strategies for success 2002-2005. New York: UNICEF

WCC Study Document 1997. Facing AIDS: The challenge, the churches' response. Geneva: World Council of Churches

Weinreich, S \& Benn, C 2004. AIDS: Meeting the challenge data, facts, background. Geneva: WCC Publication.

World Bank Policy Research Report 1999. Confronting AIDS. New York: Oxford.

The World Bank 2002. Education and HIV/AIDS: A window of hope. Washington, DC: The World Bank 